American Journal of Pharmaceutical Education 2013; 77 (5) Article 90.

\title{
STATEMENTS
}

\section{A Looming Joblessness Crisis for New Pharmacy Graduates and the Implications It Holds for the Academy}

\author{
Daniel L. Brown, PharmD \\ Lloyd L. Gregory School of Pharmacy, Palm Beach Atlantic University, West Palm Beach, Florida \\ Submitted January 1, 2013; accepted February 17, 2013; published June 12, 2013.
}

The new millennium ushered in a period of hope and change for the profession of pharmacy. The doctor of pharmacy (PharmD) degree became the exclusive first professional degree as of 2000 , bringing with it expectations for a dramatic expansion of direct patient care roles for pharmacists. Just 1 year later the pharmacy academy began a period of unprecedented growth, fueled by a longstanding shortage of pharmacists and an outstanding job market for new pharmacy graduates, making jobs for PharmD graduates easy to find and causing salaries to spiral upward. As a result, the PharmD degree became a hot commodity, generating a seemingly inexhaustible supply of applicants to colleges and schools of pharmacy. Inevitably, higher education came to see pharmacy as a "golden goose."

But no goose harbors an infinite supply of golden eggs, and the inordinate rate of academic growth that ensued has put the academy at risk, along with its students. Calls for measured academic growth, brought forth in published commentaries in 2005 and 2010, went largely unnoticed. ${ }^{1,2}$ The house of student delegates of the American Pharmacists Association-Academy of Student Pharmacists even weighed in on the subject in 2012 by approving resolution 2012:2 - Creation, Expansion, or Reductions of Schools and Colleges of Pharmacy Relative to Pharmacist Demand, which called upon current and future schools to evaluate the demand for pharmacists before taking action. ${ }^{3}$ Remarkably, most leaders of pharmacy organizations and academic institutions remained relatively silent on the matter.

This commentary examines the massive increase in the number of pharmacy graduates since 2001 and the vast overestimations, in the author's opinion, made back in 2001 about the number of pharmacists that would be needed by 2020. It also identifies potential implications

Corresponding Author: Daniel L. Brown, PharmD, Professor of Pharmacy Practice, Lloyd L. Gregory School of Pharmacy, Director of Faculty Development, Palm Beach Atlantic University, PO Box 24708, West Palm Beach, FL 33416. Tel: 561-803-2754. Fax: 561-803-2731. E-mail: daniel_brown@pba.edu of the changing pharmacist job market for the pharmacy academy.

\section{PROJECTED MANPOWER NEEDS}

In 2001, the Pharmacy Manpower Project sponsored a conference of 2 dozen pharmacy experts to project a vision of pharmacy services and manpower deployment for the year $2020{ }^{4}$ The participants envisioned a significant expansion of the pharmacist workforce and a shift in their roles and responsibilities from order fulfillment to patient care. Based on a needs forecast, they estimated that by 2020 there would be a $27 \%$ decrease in the number of pharmacist full-time equivalents (FTEs) engaged predominantly in order filling $(136,400$ to 100,000$)$ and an increase in the pharmacist FTEs providing primary patient services $(30,000$ to 165,000$)$. Overall, they projected a need for 417,000 pharmacist FTEs by 2020, and given the expected supply of only 260,000 pharmacist FTEs, a shortfall of 157,000 by $2020 .{ }^{4}$ However, their analysis assumed that the academy would add only 3 new PharmD programs every 10 years.

\section{GROWTH OF THE ACADEMY}

The size of the academy was relatively stable during the 1980s and 1990s. In 2000, there were 80 colleges and schools of pharmacy in the United States. Since then, 48 new programs have been established and 2 schools combined into 1 college, bringing the total to 127 accredited colleges and schools as of fall 2012-a $60 \%$ increase from $2000 .{ }^{5}$

According to AACP reports, there were 7,000 firstprofessional PharmD degree graduates in 2001 and 11,931 in 2011 , a $70 \%$ increase. ${ }^{6,7}$ Despite the rapid rate at which new pharmacy colleges and schools have been established, even greater growth of the academy has resulted from the expansion of previously existing programs. Of the increase in graduates from 2001 to 2011 by 4,931 , only $1,886(38 \%)$ can be attributed to new pharmacy programs; $62 \%$ of the increase resulted from the expansion of existing programs. Since 2001, 31 colleges and schools increased their number of PharmD graduates by more than 


\section{American Journal of Pharmaceutical Education 2013; 77 (5) Article 90.}

$50 \%{ }^{6,7}$ There are now 41 satellite campuses -5 of which are in a state other than that of the parent program. ${ }^{5}$ Growth has been widespread, affecting every region of the country. Twenty-one states are projected to increase the number of statewide graduates by $100 \%$ or more during the 15-year period from 2001 to 2016 (Table 1). ${ }^{8}$

The growth has yet to abate. Although 27 new pharmacy colleges and schools had not graduated a class as of 2011, their class sizes totaled 2,250 students. By 2016, when the graduates of these colleges and schools are included in the count and when the recent expansion of existing programs has taken effect, the number of PharmD graduates will range between 14,000 and 15,000 per year, more than double the number in 2001.

\section{TRENDS IN THE PHARMACY WORKFORCE}

The Pharmacy Workforce Center (PWC), formerly known as the Pharmacy Manpower Project, Inc, tracks the pharmacist workforce for multiple pharmacy organizations. $^{7}$ The primary data element compiled by the PWC is the aggregate demand index (ADI) which is derived from feedback obtained from a nationwide panel of participants who are engaged in hiring pharmacists. Panel members report their impressions of the pharmacist job market to PWC on a monthly basis using a 5-point scale, where $5=$ high demand — difficult to fill open positions; 4 = moderate demand - some difficulty filling open positions; $3=$ demand in balance with supply; $2=$ demand is less than the pharmacist supply available; and $1=$ demand is much less than the pharmacist supply available. ${ }^{9}$

A national 10-year trend map of ADI shows that it remained fairly steady at a level of about 4 (moderate demand) from 2002 through early 2008 , indicative of a modest but stable pharmacist shortage (Figure 1). ${ }^{10}$ However, the $\mathrm{ADI}$ then began a downward trend that brought it closer to the "equilibrium point" of 3 in 2010, where it has hovered since. The drop in ADI of a full point in just a couple of years, in contrast to predictions of a persistent pharmacist shortage for many years to come, is cause for concern. The November 2012 regional ADI results shed a bit more light on the job market and might serve as a harbinger of what lies ahead. The Northeast, with several states already having demonstrated major academic growth, has seen the ADI drop to $2.85 .^{11}$ Several states in the South are about to drop below 3.0 in the not-too-distant future (Florida already has), and other regions will follow suit shortly thereafter. Furthermore, the November 2012 national ADI for community pharmacies was only 2.83 , suggesting that the most prevalent pharmacy practice setting is already showing a net surplus of pharmacists nationwide. ${ }^{12}$
Table 1. First Professional Degree Pharmacy Graduates by State for the Years 2001, 2011, and Projected for 2016

\begin{tabular}{|c|c|c|c|c|}
\hline State & 2001 & 2011 & $2016^{a}$ & $\begin{array}{c}\text { 15-Year } \\
\text { Growth, \% }\end{array}$ \\
\hline Alabama & 186 & 246 & 246 & 32 \\
\hline Arizona & 57 & 203 & 203 & 256 \\
\hline Arkansas & 71 & 112 & 169 & 138 \\
\hline California & 584 & 849 & 949 & 63 \\
\hline Colorado & 63 & 121 & 192 & 205 \\
\hline Connecticut & 54 & 98 & 174 & 222 \\
\hline $\mathrm{DC}$ & 62 & 59 & 59 & -5 \\
\hline Florida $^{c}$ & 319 & 712 & 921 & 189 \\
\hline Georgia $^{c}$ & 179 & 353 & 480 & 168 \\
\hline Hawaii & 0 & 84 & 84 & NA \\
\hline Idaho & 48 & 59 & 59 & 23 \\
\hline Illinois & 327 & 437 & 658 & 101 \\
\hline Indiana & 222 & 272 & 339 & 53 \\
\hline Iowa & 154 & 211 & 211 & 37 \\
\hline Kansas & 87 & 101 & 101 & 16 \\
\hline Kentucky & 77 & 190 & 190 & 147 \\
\hline Louisiana & 178 & 241 & 241 & 35 \\
\hline Maine & 0 & 0 & 156 & NA \\
\hline Maryland & 91 & 146 & 273 & 200 \\
\hline Massachusetts $^{c}$ & 427 & 547 & 567 & 33 \\
\hline Michigan & 250 & 296 & 309 & 24 \\
\hline Minnesota & 71 & 155 & 155 & 118 \\
\hline Mississippi & 56 & 63 & 109 & 95 \\
\hline Missouri & 211 & 297 & 297 & 41 \\
\hline Montana & 53 & 65 & 65 & 23 \\
\hline Nebraska & 155 & 216 & 216 & 39 \\
\hline Nevada $^{c}$ & 0 & 188 & 138 & NA \\
\hline New Hampshire ${ }^{\mathrm{c}, \mathrm{d}}$ & 0 & $\mathrm{c}$ & 50 & NA \\
\hline New Jersey & 97 & 212 & 293 & 202 \\
\hline New Mexico & 74 & 79 & 79 & 7 \\
\hline New York & 379 & 824 & 959 & 153 \\
\hline North Carolina & 189 & 315 & 378 & 100 \\
\hline North Dakota & 59 & 84 & 84 & 42 \\
\hline Ohio & 373 & 588 & 638 & 71 \\
\hline Oklahoma & 84 & 197 & 197 & 135 \\
\hline Oregon & 100 & 185 & 185 & 85 \\
\hline Pennsylvania & 468 & 933 & 936 & 100 \\
\hline Rhode Island & 80 & 89 & 89 & 11 \\
\hline South Dakota & 45 & 67 & 67 & 49 \\
\hline South Carolina $^{c}$ & 80 & 182 & 320 & 300 \\
\hline Tennessee & 90 & 272 & 542 & 502 \\
\hline Texas & 340 & 626 & 656 & 93 \\
\hline $\operatorname{Utah}^{\mathrm{c}}$ & 47 & 50 & 159 & 238 \\
\hline Vermont ${ }^{\mathrm{c}, \mathrm{d}}$ & 0 & 0 & 66 & NA \\
\hline Virginia & 121 & 319 & 319 & 164 \\
\hline Washington & 147 & 171 & 196 & 33 \\
\hline West Virginia & 49 & 162 & 238 & 386 \\
\hline
\end{tabular}




\section{American Journal of Pharmaceutical Education 2013; 77 (5) Article 90.}

Table 1. (Continued)

\begin{tabular}{lrrrc}
\hline State & $\mathbf{2 0 0 1}$ & $\mathbf{2 0 1 1}$ & $\mathbf{2 0 1 6}^{\text {a }}$ & $\begin{array}{c}\text { 15-Year } \\
\text { Growth, \% }\end{array}$ \\
\hline Wisconsin & 100 & 136 & 217 & 117 \\
Wyoming $^{\mathbf{b}}$ & 44 & 48 & 48 & 9 \\
TOTAL $^{\mathrm{e}}$ & 6948 & 11869 & 14277 & 105 \\
\hline
\end{tabular}

a Projections for 2016 are based on the 2011 values for existing schools and $95 \%$ of class size for schools starting after 2011. Data taken from www.aacp.org and www.pharmcas.org.

${ }^{b}$ Percent growth from 2001 to 2016.

${ }^{c}$ LECOM, Roseman, Albany, Mass-Worchester, and South (GA) each have a satellite program in another state (FL, UT, VT, NH and $\mathrm{SC}$, respectively). AACP reports all graduates within a program's home state. For this table, projected 2016 graduates of satellite programs have been shifted to the state of graduation.

${ }^{\mathrm{d}}$ Alaska and Delaware do not have a pharmacy school. New Hampshire and Vermont only have a satellite PharmD program from a school in another state.

e These totals do not include graduates in Puerto Rico or Lebanon as reported by AACP.

Institutional pharmacy shows similar trends. Pharmacy Forecast 2013-2017, a strategic planning report for institutional pharmacy, reports that the vacancy rate for pharmacists in hospital practice dropped from $7.2 \%$ in 2002 to $2.4 \%$ in $2011 .^{13}$ The report notes that although the market for staff pharmacists has leveled off, it remains difficult to fill some managerial and clinical specialist positions. This phenomenon might have been exacerbated by the rapid expansion of academia, which has created a bountiful supply of new leadership and clinical positions to be filled since 2001 .

Along with an increasing rate of production of pharmacy graduates, a lower-than-expected creation of new pharmacist jobs also serves as a critical component of the pharmacy manpower equation. The projected need for pharmacy services in 2020 assumed a reduction of 36,400 pharmacist FTEs needed for dispensing and a pronounced increase of 135,000 FTEs for primary care services. ${ }^{4}$ This role transformation is simply not happening, at least not at the rate or extent predicted. According to results from the 2009 National Pharmacist Workforce Survey, $70 \%$ of pharmacist time in the community setting is devoted to dispensing, with just $10 \%$ spent on patient care activities. ${ }^{14}$ In hospitals and other patient care settings, $43 \%$ of pharmacist time was allocated to dispensing activities, compared to $27 \%$ allocated for direct patient care. The reasons for which medication therapy management services and primary care activities in ambulatory clinics have not dramatically impacted the pharmacist job market are beyond the scope of this commentary. However, there is no disputing that direct patient care jobs for pharmacists outside of acute care facilities have been slow to develop. Furthermore, not much has changed in community pharmacy practice to enhance the level of direct patient care services provided with every prescription. Community pharmacy jobs are still more closely linked to prescription volume than to the demand for patient care services. ${ }^{15}$

\section{THE MATH OF SUPPLY AND DEMAND}

When considering the dynamics of increasing the supply of pharmacy graduates into the job market, one must account for a 4-year lag period from the time at which a PharmD program starts or expands. Thereafter, following graduation of the first new or expanded class, it takes another 2 to 3 years for the job market to equilibrate, as it adjusts to a higher annual input of graduates. From that perspective, the net impact of academic growth is best measured when equilibrium is achieved - about 6 to 7 years after the initial increase in the number of students entering a PharmD program. Even if 2012 proves to be the last year of major academic expansion, the full impact will not be felt until 2018, at which time the job market will have to assimilate new pharmacists at a rate of about 15,000 per year. Contrast that rate with the 30 -year period

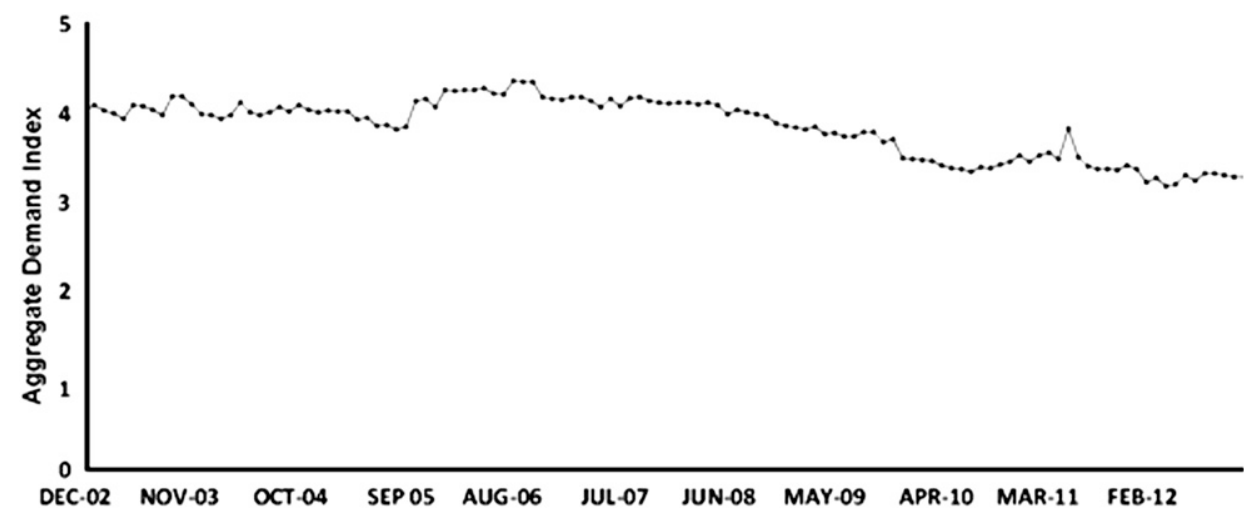

Figure 1. Plot of monthly national averages of the Aggregate Demand Index for the 10-year period of December 2002 through November 2012. ${ }^{10}$ Note the downward trend of data points that started in June of 2008. 


\section{American Journal of Pharmaceutical Education 2013; 77 (5) Article 90.}

from 1974 to 2003, during which the annual number of pharmacy graduates ranged between 6,000 and $8,000 .{ }^{16}$ The number surpassed 8,000 for the first time in 2004. By 2008 , it had risen to 10,000 . It exceeded 12,000 in 2012 and is poised to exceed 14,000 by $2016 .^{7}$

No one can question that producing the 2003 rate of 6,000 to 8,000 graduates a year was not sufficient. In retrospect, however, it would have been prudent for the academy to engage in a plan of moderate growth up to about 10,000 graduates per year and then reassess the need to expand further. Realistically, a graduation rate in the range of 10,000 to 12,000 a year is probably warranted. The math is not complicated, which suggests that it may have been overlooked due to the lure of economic gain, a possibility that is beyond the scope of this paper.

The health needs of aging baby boomers and the Affordable Care Act could serve as mitigating factors to increase the demand side of the pharmacy manpower equation, though it is likely to be a matter of "too little too late." Even if the job market is able to accommodate up to 12,000 graduates a year for the next several years, that still translates into at least 3,000 graduates each year who will not find suitable employment- $20 \%$ of the cohort of new graduates! Despite the overall unemployment rate for the profession remaining relatively low, the joblessness rate among new graduates could be staggeringly high. In the 2012 Pharmacy Graduating Student Survey conducted by the American Association of Colleges of Pharmacy (AACP), $88.7 \%$ of graduates indicated that they had taken out student loans, with an average loan amount of $\$ 123,000 .{ }^{17}$ While the potential of a $20 \%$ (or higher) joblessness rate among new pharmacy graduates is alarming enough, the looming economic hardships and personal tragedies are incalculable.

\section{IMPLICATIONS FOR THE ACADEMY}

Unfortunately, it is too late to call for the academy to pursue a more prudent plan of growth. To paraphrase an old cliché, "The horse is out of the barn." The pendulum has swung so far to the supply side that the market is about to take over, forcing the engine of academic growth to finally grind to a halt. But there will be a high price to pay in the form of a pharmacist surplus for years to come until the market establishes a new manpower equilibrium.

Ironically, academic expansion is not only contributing to new graduate joblessness, but it has also functioned to mask the problem. By creating a plethora of pharmacy practice faculty positions, the academy has provided employment for hundreds of pharmacists with advanced training who might have otherwise brought more attention to a weakening job market outside of academia. Consequently, when academic growth subsides and vacant faculty positions are no longer plentiful, pharmacists coming out of residency training will find it increasingly difficult to secure jobs commensurate with their abilitiesparticularly if they have specialized in ambulatory care.

New PharmD and/or residency graduates will not be the only victims of academic overgrowth. The academy itself will suffer repercussions. Awareness of new graduate joblessness will eventually lead to a decrease in applications to pharmacy colleges and schools, making it more difficult to meet enrollment targets. Risks of diminished enrollment will jeopardize anticipated tuition revenue that has been counted on to fund faculty positions and/or new facilities. Economic pressures may inevitably force downsizing of programs, if not outright closing of some colleges and schools. If that occurs, some faculty positions likely will be lost.

\section{CHALLENGES GOING FORWARD}

Regardless of the job market, those new graduates who are "fittest" will be able to find employment. But the profession of pharmacy should not fall victim to viewing graduates as commodities who must fend for themselves in Darwinian fashion. Some might opine that the profession would benefit from filtering out its less capable pharmacists, but faculty members and administrators must not become insensitive to the plight of each graduate amid a backdrop of broader institutional concerns. The academy must honor its fiduciary responsibility as teachers, first and foremost, to serve the best interests of every student. The academy exists for students and because of students - the reality of which is going to become gravely evident as 2020 approaches. Pharmacy colleges and schools would be wise to revisit their respective strategic plans and prepare for a new era in which the challenges of recruiting and admitting student applicants will be vastly different from just a few years ago.

In the meantime, it is incumbent upon the academy to responsibly focus on that which is within its control. Growth of the academy needs to cease forthwith. Institutions considering establishment of a new PharmD program should be discouraged from doing so by all sectors of the profession. Existing programs contemplating expansion should seriously consider putting their plans on hold.

All of the profession's organizations need to focus more heavily on establishing new pharmacist roles and activities that will create sustainable jobs as rapidly as possible. The patient care vision of pharmacists widely employed as ambulatory clinic practitioners may need to give way to a more practical vision of a new breed of community pharmacy practitioner, such that new jobs are the result of expanded patient care roles rather than increased prescription volume or the construction of new 


\section{American Journal of Pharmaceutical Education 2013; 77 (5) Article 90.}

stores. ${ }^{15}$ To better influence job creation, academia would be well served to pay greater attention to where the majority of pharmacists practice: community retail pharmacies. If the academy is to remain on a path of growth, let the emphasis shift from PharmD expansion to the formation of partnerships that establish new community pharmacy residencies. That is where the innovative clinical leaders of tomorrow are most needed.

No one could have anticipated the magnitude of academic growth that has taken place since 2000. Likewise, no one knows what the future holds for those who are about to embark on a career in pharmacy. Those in academia should look to the future with hope and optimism, born of the knowledge that the academy has done everything possible to prepare the next generation of pharmacists for whatever lies ahead.

\section{REFERENCES}

1. Hussar DA. How many colleges of pharmacy is enough? $J \mathrm{Am}$ Pharm Assoc. 2005:45(4):428-431.

2. Brown DL. From shortage to surplus: the hazards of uncontrolled academic growth. Am J Pharm Educ. 2010;74(10):Article 185.

3. American Pharmacists Association Academy of Student Pharmacists. Active Resolutions. APhA-ASP Adopted Resolutions 1973-2012. http://www.pharmacist.com/sites/default/files/files/ APhA-ASP\%20Adopted\%20Resolutions\%20-\%20Updated $\%$ 20September\%202012.pdf. Accessed January 5, 2013.

4. Knapp DA. Professionally determined need for pharmacy services in 2020. Am J Pharm Educ. 2002;66(Winter):421-429.

5. Accredited Programs. Accreditation Council for Pharmacy Education. https://www.acpe-accredit.org/shared_info/ programsSecure.asp. Accessed January 6, 2013.

6. American Association of Colleges of Pharmacy. Table 26. Number of Degrees Conferred by 2000-01 by School, Degree and Gender. http://www.aacp.org/resources/research/institutionalresearch/ Documents/01DegConf.pdf. Accessed May 20, 2013.

7. American Association of Colleges of Pharmacy. Table 22. Number of Degrees Conferred 2010-11 by School, Degree and Gender. http://www.aacp.org/resources/research/ institutionalresearch/Documents/11_Degrees\%20Conferred.pdf. Accessed May 20, 2013.
8. Pharmacy College Application Service. Colleges and schools by institutional name. http://www.pharmcas.org/collegesschools/ directoryalpha.htm. Accessed January 5, 2013.

9. American Association of Colleges of Pharmacy. Pharmacy workforce center. http://www.aacp.org/resources/research/ pharmacymanpower/Pages/default.aspx. Accessed February 10, 2013. 10. ADI data for national (Dec 2002 to Nov 2012). Pharmacy Workforce Center. American Association of Colleges of Pharmacy. http://www.pharmacymanpower.com/trends.jsp. Accessed February $10,2013$.

11. Regional and Divisional Demand Index - Nov 2012. Pharmacy Workforce Center. American Association of Colleges of Pharmacy. http://www.pharmacymanpower.com/region.jsp. Accessed February $10,2013$.

12. National Pharmacist Demand by Practice Setting - Nov 2012. Pharmacy Workforce Center. American Association of Colleges of Pharmacy. http://www.pharmacymanpower.com/setting.jsp.

Accessed February 10, 2013.

13. Pharmacy Workforce. Pharmacy Forecast 2013 - 2017. American Association of Health-System Pharmacists Research and Education Foundation. http://www.nxtbook.com/ygsreprints/ASHPFoundation/ d28547_ashpf_forecastbook2013/\#/14. Accessed May 20, 2013. 14. Midwest Pharmacy Workforce Research Consortium. Work activities for pharmacists working full-time. Final Report of the 2009 National Sample Survey of the Pharmacist Workforce to Determine Contemporary Demographic and Practice Characteristics. http:// www.aacp.org/resources/research/pharmacymanpower/Documents/ 2009\%20National\%20Pharmacist $\% 20$ Workforce $\% 20$ Survey $\% 20$ \%20FINAL\%20REPORT.pdf. Accessed January 5, 2013.

15. Brown D. The paradox of pharmacy: a profession's house divided. J Am Pharm Assoc. 2012:e139-e143. doi:10.1331/

JAPhA.2012.11275.

16. Midwest Pharmacy Workforce Research Consortium. Figure 1.2: number of U.S. pharmacy school graduates: 1960-2008. Final Report of the 2009 National Sample Survey of the Pharmacist Workforce to Determine Contemporary Demographic and Practice Characteristics. http://www.aacp.org/resources/research/pharmacymanpower/ Documents/2009\%20National\%20Pharmacist $\% 20$ Workforce $\%$ 20Survey\%20-\%20FINAL\%20REPORT.pdf. Accessed January 5, 2013.

17. American Association of Colleges of Pharmacy. Pharmacy Graduating Student Survey Summary Report 2012. http://www.aacp. org/resources/research/institutionalresearch/Documents/ 2012_GSS_final\%20summary\%20report_all\%20schools_105_ with\%20charts.pdf. Accessed January 5, 2013. 